\title{
PENGARUH REBUSAN DAUN SALAM TERHADAP PENURUNAN KADAR ASAM URAT DI DESA MALANGGATEN KECAMATAN KEBAKKRAMAT KABUPATEN KARANGANYAR
}

\author{
Ditya Yankusuma S. ${ }^{1}$, Pradita Putri ${ }^{2}$
}

\begin{abstract}
Introduction of this research is the result Uric acid is produced by the body, so that its presence can be normal in the blood and urine. While the survey results indicate that approximately 20 residents suffer from gout. Results of preliminary interviews with several residents of approximately 10 people, they do not know that bay leaves can lower uric acid levels in the blood.

Purpose of the study was to determine the effect of bay leaf decoction to decrease levels of uric acid in the village Malanggaten.

Subjects of the study were all patients with uric acid in the village of the District Malanggaten Kebakkramat number of 12 people who met the inclusion criteria were already writers set.

Results showed that there was an effect decoction of leaves to decrease levels of uric acid in the village Malanggaten obtained test results with Dependent paired t test ( $t$ test) by SPSS for windows series 18 with $\alpha=5 \%(0: 05)$ obtained $p$ 0.000 that $p<0: 05$, which means Ho rejected so that it can be concluded that there is influence of decoction of leaves to decrease levels of uric acid in the village Malanggaten.

Conclusion of research is the effect of bay leaf decoction to decrease levels of uric acid in the village of the District Malanggaten Kebakkramat .
\end{abstract}

Keywords: Bay Leaf, Uric Acid

\section{PENDAHULUAN}

Asam urat adalah hasil produksi oleh tubuh, sehingga keberadaannya bisa normal dalam darah dan urin. Akan tetapi sisa dari metabolisme protein makanan yang mengandung purin juga menghasilkan asam urat. Oleh karena itulah kadar asam urat di dalam darah bisa meningkat bila seseorang terlalu banyak mengkonsumsi makanan yang mengandung purin tinggi (seperti ekstrak daging, kerang, dan jeroan seperti hati, ginjal, limpa, paru, otak). (Misnadiarly, 2007)

Menurut badan kesehatan dunia WHO, penderita asam urat pada tahun 2007 diperkirakan mencapai 230 juta dan angka tersebut diperkirakan akan meningkat tajam pada tahun 2020. Jumlah penderita asam urat bertambah banyak dari tahun 2004 dan menyerang pada usia pertengahan 40-59 tahun. Penyakit asam urat yang terus meningkat prevalensinya, baik di negara maju maupun berkembang dan hanya sedikit penderita asam urat yang terkontrol dengan baik. Di Amerika angka kejadian asam urat mencapai 2-13\% sedangkan di Jawa Tengah adalah sebesar $24,3 \%$ pada laki-laki dan $11,7 \%$ pada perempuan. (Achmad,2008)

Desa Malanggaten merupakan desa yang terletak di Kelurahan Desa 
Malanggaten,

Kebakkramat,

Kecamatan

Karanganyar.

Kabupaten

sementara menunjukkan survey

sementara menunjukan bahwa kurang lebih 20 warga menderita asam urat. Hasil wawancara awal dengan beberapa warga kurang lebih 10 orang, mereka belum mengetahui bahwa daun salam dapat menurunkan kadar asam urat dalam darah. Melihat fenomena di atas maka peneliti memandang perlu untuk melakukan penelitian tentang "Pengaruh Rebusan Daun Salam terhadap Penurunan Kadar Asam Urat di Desa Malanggaten Kecamatan Kebakkramat”.

\section{TUJUAN PENELITIAN}

Untuk mengetahui pengaruh rebusan daun salam terhadap penurunan kadar asam urat di Desa Malanggaten Kecamatan Kebakkramat.

\section{DESAIN PENELITIAN}

Penelitian ini merupakan jenis penelitian quasi eksperimental dengan rancangan penelitian pretest-posttest untuk mengetahui pengaruh pemberian rebusan daun salam terhadap penurunan kadar asam urat, dengan membandingkan kadar asam urat sebelum diberi rebusan daun salam dan sesudah diberi rebusan daun salam.

\section{POPULASI, SAMPEL, \\ TEHNIK SAMPLING} DAN

Populasi adalah seluruh subjek atau objek dengan karakteristik tertentu yang akan diteliti. Bukan hanya objek atau subjek yang dipelajari, tetapi seluruh karakteristik atau sifat yang dimiliki subjek atau objek tersebut. (Hidayat, 2009) Populasi yang digunakan dalam penelitian ini adalah seluruh penderita asam urat di Desa Malanggaten Kecamatan Kebakkramat sejumlah 20 orang.

Sampel adalah sebagian dari populasi yang akan dijadikan sebagai responden. (Hidayat, 2009) Dari 20 responden, penulis mendapatkan 12 sampel yang digunakan sebagai penelitian, dimana 12 responden tersebut sudah memenuhi kriteria inklusi yang sudah penulis tetapkan.

Teknik sampling yang digunakan adalah teknik purposive sampling yaitu cara pengambilan sampel yang sesuai dengan tujuan dan kriteria yang sudah ditetapkan peneliti. (Sangadji dan Sopiah, 2010)

\section{HASIL PENELITIAN}

Berdasarkan penelitian yang dilakukan didapatkan karakteristik responden berdasarkan umur, jenis kelamin, distribusi frekuensi kadar asam urat sebelum diberi rebusan daun salam, distribusi frekuensi kadar asam urat sesudah diberi rebusan daun salam dan pengaruh rebusan daun salam terhadap penurunan kadar asam urat di Desa Malanggaten Kecamatan Kebakkramat, yaitu sebagai berikut :

Tabel 1

Distribusi Frekuensi

Kadar Asam Urat Sebelum Diberi Rebusan Daun Salam

\begin{tabular}{ccc}
\hline $\begin{array}{c}\text { Kadar } \\
\text { Asam Urat }\end{array}$ & $\mathrm{f}$ & $\%$ \\
\hline 11,7 & 1 & 8,3 \\
\hline 7,1 & 1 & 8,3 \\
\hline 7,2 & 1 & 8,3 \\
\hline 8,4 & 1 & 8,3 \\
\hline 8,7 & 3 & 25,0 \\
\hline 9,0 & 3 & 25,0 \\
\hline 9,2 & 1 & 8,3 \\
\hline 9,7 & 1 & 8,3 \\
\hline Total & 12 & 100,0 \\
\hline Mean & 8,87 & \\
Median & 8,85 & \\
St.Dev. & 1,71 & \\
\hline
\end{tabular}

Dari tabel di atas ditemukan ada 1 responden $(8,3 \%)$ dengan kadar 
asam urat $11,7 \mathrm{mg} / \mathrm{dl}, 7,1 \mathrm{mg} / \mathrm{dl}, 7,2$ $\mathrm{mg} / \mathrm{dl}, 8,4 \mathrm{mg} / \mathrm{dl}, 9,2 \mathrm{mg} / \mathrm{dl}$ dan 9,7 $\mathrm{mg} / \mathrm{dl}$. Sedangkan ada 3 responden (25\%) dengan kadar asam urat 8,7 $\mathrm{mg} / \mathrm{dl}$ dan $9,0 \mathrm{mg} / \mathrm{dl}$.

Tabel 2

Distribusi Frekuensi

Kadar Asam Urat Sesudah Diberi Rebusan Daun Salam

\begin{tabular}{ccr}
\hline $\begin{array}{c}\text { Kadar Asam } \\
\text { Urat }\end{array}$ & $\mathrm{f}$ & $\%$ \\
\hline 5,7 & 2 & 16,7 \\
\hline 5,9 & 4 & 33,3 \\
\hline 6,8 & 1 & 8,3 \\
\hline 7,2 & 1 & 8,3 \\
\hline 7,3 & 2 & 16,7 \\
\hline 7,8 & 1 & 8,3 \\
\hline 8,7 & 1 & 8,3 \\
\hline Total & 12 & 100,0 \\
\hline Mean & 6,68 & \\
Median & 6,35 & \\
St.Dev & 9,88 & \\
\hline
\end{tabular}

Dari tabel di atas ditemukan ada 2 responden $(16,7 \%)$ dengan kadar asam urat $5,7 \mathrm{mg} / \mathrm{dl}$ dan $7,3 \mathrm{mg} / \mathrm{dl}$, 4 responden $(33,3 \%)$ dengan kadar asam urat $5,9 \mathrm{mg} / \mathrm{dl}$, 1 responden $(8,3 \%)$ dengan kadar asam urat 6,8 $\mathrm{mg} / \mathrm{dl}, 7,2 \mathrm{mg} / \mathrm{dl}, 7,8 \mathrm{mg} / \mathrm{dl}$ dan 8,7 $\mathrm{mg} / \mathrm{dl}$.

Tabel 3

Perbandingan Kadar Asam Urat Sebelum Dan Sesudah Diberi Rebusan Daun Salam

\begin{tabular}{ccc}
\hline No.Res & Pre & Post \\
\hline 1 & 9,2 & 5,9 \\
\hline 2 & 8,7 & 5,7 \\
\hline 3 & 11,7 & 7,3 \\
\hline 4 & 9,0 & 8,7 \\
\hline 5 & 9,0 & 7,8 \\
\hline 6 & 7,1 & 6,8 \\
\hline 7 & 7,2 & 5,9 \\
\hline 8 & 8,4 & 7,2 \\
\hline 9 & 8,7 & 5,7 \\
\hline 10 & 9,7 & 7,3 \\
\hline 11 & 8,7 & 5,9 \\
\hline 12 & 9,0 & 5,9 \\
\hline & &
\end{tabular}

Dari tabel dapat dilihat bahwa ada perbedaan kadar asam urat sebelum diberi rebusan daun salam dan sesudah diberi rebusan daun salam. Hal tersebut dapat dilihat dari nilai kadar asam urat responden pada tabel.

Tabel 4

Pengaruh Rebusan Daun Salam Terhadap Penurunan Kadar Asam Urat

\begin{tabular}{|c|c|c|c|}
\hline \multicolumn{2}{|c|}{ Mean } & \multirow{2}{*}{ T-test } & Ket \\
\cline { 1 - 1 } Pre & Post & & Ada \\
\hline 8,87 & 6,68 & 0,000 & $\begin{array}{c}\text { Ada } \\
\text { pengaruh } \\
\text { (Ha) diterima }\end{array}$ \\
\hline
\end{tabular}

Dari data di atas diperoleh informasi bahwa untuk nilai rata-rata kadar asam urat sebelum diberi rebusan daun salam 8.87 dan sesudah diberi rebusan daun salam 6.68 maka dapat disimpulkan bahwa ada penurunan kadar asam urat setelah diberi rebusan daun salam. Hasil uji t-test adalah 0,000 yang menunjukkan bahwa ada perbedaan kadar asam urat antara sebelum dan sesudah diberi rebusan daun salam, atau dengan kata lain Ha diterima dan berarti ada pengaruh rebusan daun salam terhadap penurunan kadar asam urat di Desa Malanggaten.

\section{PEMBAHASAN}

1. Hasil Perbandingan Data Distribusi Frekuensi Kadar Asam Urat di Desa Malanggaten

Dari data yang diperoleh sebelum diberi rebusan daun salam, kadar asam urat 7,1 $\mathrm{mg} / \mathrm{dl}$ sampai $11,7 \mathrm{mg} / \mathrm{dl}$. Artinya, semua responden mempunyai kadar asam urat di 
atas batas normal. Setelah diberi rebusan daun salam, kadar asam urat responden berkisar antara 5,7 mg/dl sampai $8,7 \mathrm{mg} / \mathrm{dl}$. Dimana 7 responden dari 12 responden sudah dalam batas normal untuk kadar asam uratnya. Berdasarkan jenis kelamin, ditemukan bahwa perempuan lebih banyak dari pada laki-laki yaitu sebesar 66,7 \% dengan kadar asam urat tinggi. Hal ini sesuai yang diungkapkan oleh Agromedia (2009), bahwa secara alamiah laki - laki berusia di atas 30 tahun lebih rentan terkena penyakit asam urat. Pasalnya, kadar asam urat pada laki-laki cukup tinggi. Sementara, kadar asam urat pada wanita umumnya rendah dan baru meningkat setelah menopause. Responden wanita yang mengalami peningkatan kadar asam urat rata-rata berusia diatas 50 tahun dan sudah pada masa menopause. Ini artinya, rebusan daun salam dapat bermanfaat bagi penderita asam urat. Menurut Herliana (2013), khasiat yang terkandung dalam daun salam mempunyai beberapa senyawa- senyawa seperti minyak atsiri, tannin, dan flavonoid yang banyak terdapat dalam daunnya. Kandungan dalam daun salam tersebut yang dapat menurunkan kadar asam urat dengan jalan menghambat kerja ezim xantin oksidase sehingga dapat menghambat pembentukan asam urat.
2. Hasil Analisa Univariat Perbandingan Sebelum dan Sesudah diberi Rebusan Daun Salam

Dari data diperoleh nilai ratarata sebelum diberi rebusan daun salam (pre) adalah 8,87 lebih besar daripada setelah diberi rebusan daun salam yaitu 6,68. Untuk nilai tengah sebelum diberi rebusan daun salam adalah 8,85 sedangkan untuk post pemberian rebusan daun salam adalah 6,35 yang berarti kadar asam urat responden mengalami penurunan dari awal sebelum diberi rebusan daun salam.

Mayoritas responden pada saat sebelum dilakukan pemberian daun salam mengatakan bahwa responden sering merasakan kaku-kaku pada sendinya. Seperti yang diungkapkan oleh Misnadiarly (2007), bahwa tanda dan gejala asam urat yang sering dialami berupa rasa nyeri di persendian yang terjadi secara mendadak. Umumnya, terjadi pada malam hari atau menjelang pagi hari. Gejala lain yang muncul di antaranya kemerahan dan pembengkakan di bagian yang diserang, demam, kedinginan, dan detak jantung cepat. Pada umumnya, serangan pertama terjadi pada satu bagian sendi dan serangan akan cepat menghilang. Serangan dapat terjadi lagi, tetapi dalam jangka waktu yang lama hingga bertahun-tahun. Serangan awal yang cepat menghilang ini membuat banyak penderita tidak menyadari bahwa telah 
mengalami gejala asam urat. Apabila tidak diobati dalam jangka waktu yang lama, serangan akan lebih sering terjadi dan gejala asam urat akan menjadi lebih parah. Gejala asam urat yang sudah berat dapat menyebabkan perubahan bentuk di bagian bagian tubuh yang terserang. Perubahan bentuk biasanya terjadi di pergelangan kaki, punggung, lengan, lutut, tendon belakang, dan daun telinga.

Setelah diberi rebusan daun salam selama 7 hari, responden mengatakan bahwa badan rasanya lebih nyaman dan kaku sendi sudah berkurang.

3. Pengaruh Rebusan Daun Salam terhadap Penurunan Kadar Asam Urat di Desa Malanggaten

Dari hasil penelitian pengaruh rebusan daun salam terhadap penurunan kadar asam urat di Desa Malanggaten diperoleh hasil uji dengan Dependent paired $t$ Test (uji $t$ ) melalui program SPSS for windows seri 18 dengan $\alpha=5 \% \quad(0.05)$ diperoleh $p$ sebesar 0.000 sehingga $p<0.05$, yang berarti $\mathrm{Ha}$ diterima dan Ho ditolak sehingga dapat ditarik kesimpulan bahwa ada pengaruh rebusan daun salam terhadap penurunan kadar asam urat di Desa Malanggaten Hasil penelitian ini sejalan dengan penelitian terdahulu yang telah dilakukan oleh Ardhiyanti (2013), yang berjudul pengaruh pemberian air rebusan daun salam (syzgium polyanthum weight) terhadap penurunan kadar asam urat dengan hiperurisemia di Desa Leyengan Kecamatan Ungaran Timur Kabupaten Semarang tahun 2013. Hasil dari penelitian tersebut adalah ada pengaruh pemberian air rebusan daun salam terhadap penurunan kadar asam urat dengan hiperurisemia ( $p$-value sebesar $0,021<\alpha(0,05)$.

Hal tersebut dapat terjadi karena dipengaruhi oleh beberapa faktor baik dari responden yang kooperatif maupun dari manfaat daun salam jika dilakukan sesuai prosedur dan dengan frekuensi yang teratur serta faktor diet yang mereka jalani selama proses penelitian berlangsung. Sesuai yang di ungkapkan oleh Herliana (2013), khasiat yang terkandung dalam daun salam mempunyai beberapa senyawasenyawa seperti minyak atsiri, tannin, dan flavonoid yang banyak terdapat dalam daunnya. Kandungan dalam daun salam tersebut yang dapat menurunkan kadar asam urat dengan jalan menghambat kerja ezim xantin oksidase sehingga dapat menghambat pembentukan asam urat.

\section{KESIMPULAN}

1. Kesimpulan

a. Dari data yang diperoleh sebelum diberi rebusan daun salam, kadar asam urat $7,1 \mathrm{mg} / \mathrm{dl}$ sampai 11,7 $\mathrm{mg} / \mathrm{dl}$. Artinya, semua responden mempunyai kadar asam urat diatas batas normal. Setelah diberi 
rebusan daun salam, kadar asam urat responden berkisar antara 5,7 mg/d sampai $8,7 \mathrm{mg} / \mathrm{dl}$. Dimana 7 responden dari 12 responden sudah dalam batas normal untuk kadar asam uratnya.

b. Dari data diperoleh nilai rata-rata sebelum diberi rebusan daun salam (pre) adalah 8,87 lebih besar daripada setelah yang diberi rebusan daun salam yaitu 6,68 . Untuk nilai tengah sebelum diberi rebusan daun salam adalah 8,85 sedangkan untuk post pemberian rebusan daun salam adalah 6,35 yang berarti kadar asam urat responden mengalami penurunan dari awal sebelum diberi rebusan daun salam.

c. Dari hasil penelitian pengaruh rebusan daun salam terhadap penurunan kadar asam urat di Desa Malanggaten diperoleh hasil uji dengan Dependent paired $t$ Test (uji $t$ ) melalui program SPSS for windows seri 18 dengan $\alpha=5 \%$ (0.05) diperoleh $\mathrm{p}$ sebesar 0.000 sehingga $p<0.05$, yang berarti Ha diterima dan Ho ditolak sehingga dapat ditarik kesimpulan bahwa ada pengaruh rebusan daun salam terhadap penurunan kadar asam urat di Desa Malanggaten
2. Saran

a. Bagi Dinas Kesehatan

Bagi Dinas Kesehatan dapat digunakan sebagai acuan untuk pembinaan kesehatan terhadap penderita Asam Urat di setiap desa.

b. Bagi Masyarakat

Hasil penelitian ini agar diaplikasikan oleh responden dan keluarga dalam membantu meningkatkan kesehatan. Selain itu, masyarakat diharapkan lebih berhati-hati dalam memilih menu makanan.

c. Bagi Peneliti Selanjutnya

Diharapkan dapat dijadikan sebagai tambahan informasi untuk penelitian selanjutnya agar lebih baik lagi.

\section{DAFTAR PUSTAKA}

Agromedia. 2009. Solusi Sehat Mengatasi Asam Urat dan Rematik. PT Agromedia Pustaka, Jakarta.

Herliana, Ersi. 2013. Penyakit Asam Urat Kandas Berkat Herbal. FMedia, Jakarta.

Herman. 2014. Sandjaya. Buku Sakti Pencegahan dan Penanganan Asam Urat. Mantra Books, Yogyakarta.

Hidayat, A. Aziz Alimul. 2009. Metode Penelitian Keperawatan dan Teknik Analisa Data. Salemba Medika, Jakarta.

Mahmud D. 2008. Buku Pintar Sehat Seumur Hidup. Yayasan Media Kesehatan Alternatif Sarana Bantuan Kesehatan, Jakarta. 
Misnadiarly. 2007. Asam Urat Hiperurisemia Arthritis Gout. Pustaka Obor Populer, Jakarta.

Noor, Helmi Zairin. 2014. Buku Ajar Gangguan Muskuloskeletal. Salemba Medika, Jakarta.

Putra, Sitiatava Rizema. 2012. Panduan Riset Keperawatan dan Penulisan IImiah. DMedika, Yogyakarta.

Suyanto. 2011. Metodologi dan Aplikasi Penelitian Keperawatan. Nuha Medika, Yogyakarta.

Winasis. E.G. 2015. Penakluk Asam Urat dan Diabetes. Araska, Yogyakarta.
Ardhiyanti, Ni Wayan Rhacik. 2013. "Pengaruh Pemberian Air Rebusan Daun Salam (syzgium polyanthum w) terhadap Penurunan Kadar Asam Urat dengan Hiperurisemia di Desa Leyangan Kecamatan Ungaran Timur Kabupaten Semarang".

URL:http://perpusnwu.web.id/k aryailmiah/shared/biblio_view. php?resource_id $=2897 \&$ tab $=0$ pac. Diakses 12 Oktober 2015.

Hadi, Suyanto. 2012. "Ekstrak Herbal (Daun Salam, Jintan Hitam, Daun Seledri) dan Kadar IL-6 Plasma Penderita Hiperurisemia".

URL:http://ejournal.undip.ac.id /index.php/mmi/article/downlo ad/ 3023/2706. Diakses 12 Oktober 2015

Dosen AKPER Panti Kosala Surakarta

2 Mahasiswa AKPER Panti Kosala Surakarta 